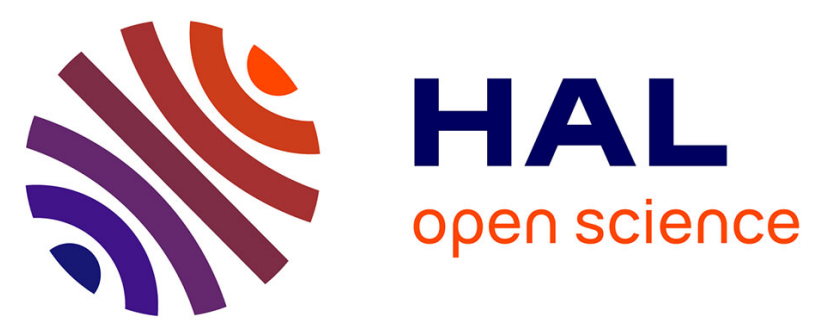

\title{
Evaluating the geographic viability of the solar water disinfection (SODIS) method by decreasing turbidity with NaCl: A case study of South Sudan
}

Brittney Dawney, Cheng Cheng, Richelle Winkler, Joshua Pearce

\section{To cite this version:}

Brittney Dawney, Cheng Cheng, Richelle Winkler, Joshua Pearce. Evaluating the geographic viability of the solar water disinfection (SODIS) method by decreasing turbidity with $\mathrm{NaCl}$ : A case study of South Sudan. Applied Clay Science, 2014, 99, pp.194-200. 10.1016/j.clay.2014.06.032 . hal-02119692

\author{
HAL Id: hal-02119692 \\ https://hal.science/hal-02119692
}

Submitted on 4 May 2019

HAL is a multi-disciplinary open access archive for the deposit and dissemination of scientific research documents, whether they are published or not. The documents may come from teaching and research institutions in France or abroad, or from public or private research centers.
L'archive ouverte pluridisciplinaire HAL, est destinée au dépôt et à la diffusion de documents scientifiques de niveau recherche, publiés ou non, émanant des établissements d'enseignement et de recherche français ou étrangers, des laboratoires publics ou privés. 


\title{
Evaluating the Geographic Viability of the Solar Water Disinfection (SODIS) Method by Decreasing Turbidity with $\mathrm{NaCl}$ : A Case Study of South Sudan
}

\author{
Brittney Dawney ${ }^{1}$, Cheng Cheng ${ }^{2}$, Richelle Winkler ${ }^{3}$, and Joshua M. Pearce ${ }^{4 *}$ \\ 1. Department of Civil Engineering, Queen's University, Kingston, Ontario, Canada \\ 2. Department of Sociology, Princeton University, Princeton, NJ, USA \\ 3. Department of Social Sciences, Michigan Technological University, Houghton, MI, \\ USA \\ 4. Department of Materials Science \& Engineering and Department of Electrical \& \\ Computer Engineering, Michigan Technological University, Houghton, MI, USA \\ * contact author: \\ 601 M\&M Building \\ 1400 Townsend Drive \\ Houghton, MI 49931-1295 \\ 906-487-1466 \\ pearce@mtu.edu
}

\begin{abstract}
While the solar water disinfection (SODIS) method of treating microbiologically contaminated water at the household level has proven to be effective at reducing incidence of diarrhea, its effectiveness is limited to waters of low turbidity. This study investigates the use of table salt $(\mathrm{NaCl})$ to reduce turbidity in water containing dispersed colloidal clay particles as a means of expanding the user base of SODIS. Jar tests were performed on solutions of a low-activity clay, simulating the general composition of soils of the Vertisol type, which are found in key developing regions. Results show that dispersions exhibited as high as 92\% particle removal efficiency. The results of this study suggest that $\mathrm{NaCl}$ in combination with as little as 30\% bentonite by mass may be used to produce a small-scale jumpstart effect by reducing turbidity to a level suitable for SODIS treatment. Soil type was mapped and overlaid with population estimates in a GIS environment to highlight geographic areas where salt+SODIS may be most viable in the case study of South Sudan. Findings suggest that the $\mathrm{NaCl}$ method could expand access to SODIS technology by about 1.56 million people who currently lack access to an improved water source in the case study.
\end{abstract}

Keywords: Vertisol; bentonite; drinking water; flocculation; SODIS; turbidity 


\section{Introduction}

Over 2.6 billion people around the world, primarily in rural regions, live without access to improved sanitation, and around a billion people do not have clean drinking water (World Health Organization 2010). The most serious implication of inadequate access to clean water for drinking, sanitation and hygiene purposes is exposure to enteric pathogens that result in chronic diarrhea including cholera, typhoid fever, and dysentery (Mintz et al. 2001; Sobsey 2002; Thapar 2004;). Diarrheal diseases remain the leading cause of annual water-, sanitation- and hygiene-related deaths (United Nations 2009) and of those affected, children under the age of five are most at risk: approximately 2.8 million people die every year from waterborne diarrheal diseases (World Health Organization 2002), and of these, around 1.4 million are children (United Nations 2010).

The provision of clean water for the world's most impoverished rural populations, particularly in sub-Saharan Africa, South America, and South Asia, remains a significant challenge. Various physical and chemical methods exist to treat turbid and microbiologically contaminated water at the household level; however, the use of these methods is restricted in many regions due to availability of resources and cost (Sobsey 2002). Low-cost open-source appropriate technologies (OSAT) are needed to provide for sustainable development needs such as safe drinking water (Buitenhuis, et al., 2010; Pearce, 2012). Solar water disinfection (SODIS) is such an OSAT and has already been proven to be effective at reducing incidence of diarrhea, particularly in children under five (Conroy et al. 1996; 2001). However, the SODIS method is most effective in lowturbidity water, which creates a significant barrier to its use in populations that lack the financial and material resources to reduce turbidity through filtration or existing coagulation-flocculation methods.

This study investigates the use of table salt $(\mathrm{NaCl})$ in reducing turbidity in water caused by colloidal clay particles common to certain developing rural regions in Africa, India, and South America. The potential use of $\mathrm{NaCl}$ to reduce turbidity has been explored and shown to be effective (Dawney \& Pearce, 2012), particularly in samples containing a high concentration of high-activity clay. The current study aims to examine this phenomenon further by investigating the effectiveness of $\mathrm{NaCl}$ at reducing turbidity in water containing a mixture of high- and low-activity clays, simulating naturally occurring soils of the Vertisol type. First, the relevant literature is reviewed on the need for clean water, the SODIS method, the coagulating potential for $\mathrm{NaCl}$, and finally Vertisols. Then, the method is outlined by which combinations of clays representing those of the Vertisol type were tested at various levels of turbidity for their behaviour with five different concentrations of $\mathrm{NaCl}$. The resulting supernatant was tested for sodium content and the results are then analyzed and discussed. Finally, data on soil types was overlaid with population distribution in South Sudan to illustrate areas where this approach is most technically viable, and to estimate the number of South Sudanese people who may benefit from the salt+SODIS approach.

\section{Background}

Need for Clean Water

Of the 2.6 billion people without access to improved sources of water, almost two thirds live on less than two dollars a day, and one third on less than a dollar a day, with affected populations being concentrated in South Asia and sub-Saharan Africa (United 
Nations 2009). Therefore, there is a great need for simple, low-cost water treatment technologies designed for household use (Sobsey 2002; United Nations 2009, 2010), as even microbiologically clean source water often becomes re-contaminated through its transport, handling, and storage. Point-of-use household water treatments (HWT) have significant potential for reducing secondary contamination of water (Mintz et al. 2001; Sobsey 2002;Fewtrell et al. 2005; Meierhofer \& Landolt 2009) and studies of household interventions have shown to be more effective at reducing diarrhea incidences than interventions at the water source level (Fewtrell et al. 2005; Clasen et al. 2007). Although there appears to be a lack of conclusive evidence on the exact effect of various interventions due to publication biases (Cairncross et al. 2010), there nonetheless is a great deal of evidence that shows that the frequency and intensity of diarrhea associated with enteric water-, sanitation- and hygiene-related pathogens can be reduced by improving the microbial quality of water (Mintz et al. 2001; Sobsey 2002; United Nations 2009). Various methods exist to effectively treat turbid and microbiologically contaminated water at the household level, including chlorination, ceramic filtration, boiling, and coagulation-flocculation via natural reagents such as Moringa Oleifera seed extract (Ferreira et al. 2011); however, the use of these methods is restricted in many regions due to availability of resources and cost (Sobsey 2002).

The Republic of South Sudan is used in this paper as a case example demonstrating the potential applicability of the salt+SODIS method for improving lives. South Sudan is one of the least developed countries in the world, and only about $50 \%$ of the population has access to an improved drinking water source (Southern Sudan Centre for Census, Statistics, and Evaluation [SSCCSE] 2010). After decades of civil war, Southern Sudan seceded from the north on July 9, 2011, becoming the Republic of South Sudan. Still, conflict and violence between ethnic groups and between Sudan and South Sudan continue, and thousands remain in refugee camps (NYT 2012).

\section{Solar Water Disinfection}

Solar water disinfection (SODIS) has shown to appreciably reduce incidence of diarrhea, particularly in children under five (Conroy et al. 1996; 1999; 2001; Graf et al. 2010; Rai et al. 2010; Rose et al. 2006). The technology functions through the synergistic effect of UV-A radiation and heat, as proven to be effective under both natural and simulated laboratory conditions (Joyce et al. 1996; McGuigan et al. 1998; Rijal \& Fujioka 2001; Berney et al. 2006; Heaselgrave et al. 2006; Dejung et al. 2007; MéndezHermida 2007; Boyle et al. 2008; Gómez-Couso 2009). Although SODIS can work at higher turbidities (Conroy et al. 1996; McGuigan, et al., 1998), its effectiveness is weakened in water of more than 30 nephalometric turbidity units (NTU). Thirty NTU is the recommended maximum level of turbidity by the primary field proponent of the SODIS method - the Swiss Federal Institute of Aquatic Science and Technology (Eawag, German acronym for Eidgenössische Anstalt für Wasserversorgung, Abwasserreinigung und Gewässerschutz). This demonstrates the need for a simple, affordable pre-treatment of turbid water for subsequent solar disinfection.

\section{Sodium Chloride (SODIS) as a Coagulant}

The application of coagulation-flocculation as a means of reducing turbidity is well understood and is used extensively in industrial water and wastewater treatment 
processes. However, at the household level in developing countries, the high cost of conventional coagulants such as alum and ferric salts, or a lack of availability of natural coagulants such as Moringa Oleifera, often makes coagulation-flocculation an impractical option (Sobsey 2002). The flocculating behavior of different types of clay in aqueous solutions containing $\mathrm{NaCl}$ has been explored (Hsi \& Clifton 1960; Gibbs 1983, 1985; Akther et al. 2008; Panayiotopoulos et al. 2004; Dawney \& Pearce 2012). The use of $\mathrm{NaCl}$ as a means of reducing turbidity prior to SODIS treatment was examined by Dawney and Pearce (2012), when it was shown that $\mathrm{NaCl}$ in combination with sodium bentonite (a high-activity clay) can significantly reduce turbidity to as low as 4 NTU. In particular, the application of this technology to water that is to be used for hygiene and sanitation purposes shows promise, as the sodium content remaining in the supernatant is not as limiting (Dawney \& Pearce, 2012). For water that is to be used for drinking purposes, sodium remaining in the supernatant must be examined and compared to allowable health limits and taste thresholds unique to the target populations, of which there is a significant gap in the data. In general, however, it is expected that the target SODIS user base is likely to have lower daily sodium intakes than populations from less impoverished regions (Elliott \& Brown 2006). It follows that users of SODIS will therefore have lower allowable and tolerable sodium limits, which must be taken in to consideration when evaluating the viability of this technology.

\section{Vertisols}

Vertisols are heavy clay soils containing a high proportion of swelling clays (at least 30\%), and are found mainly in tropical, subtropical, semi-arid to subhumid and humid climates that alternate between distinct wet and dry seasons (Batonio et al. 2006, Food and Agriculture Organization 2006). Swelling clays shrink in dry conditions, producing pronounced surficial cracks, and expand under wet conditions to become very sticky, with a low saturated hydraulic conductivity (Food and Agriculture Organization 2006). The mineral responsible for the general attributes of vertisols and their properties is montmorillonite (the major component of bentonite), which belongs to the smectite family of minerals (Eswaran \& Cook 1988). The primary cations in montmorillonite are calcium $\left(\mathrm{Ca}^{2+}\right)$, magnesium $\left(\mathrm{Mg}^{2+}\right)$, potassium $(\mathrm{K})$, and sodium $(\mathrm{Na})$, giving the clay a high cation exchange capacity (Eswaran \& Cook 1988),

Vertisols cover approximately 335 million hectares (ha) worldwide (Food and Agriculture Organization 2006). They occur extensively in India (72 million ha, or 22\% of Indian land), northern Australia (71 million ha), and Sudan (63 million ha) (Murthy 1982, Swindale 1988). They also occur in Ethiopia, Tanzania, Chad, Somalia, and parts of Central and South America (Swindale 1988, Food and Agriculture Organization 2006, Hadden 2007).

\section{Research Goals}

$\mathrm{NaCl}$ in combination with pure clay solutions has shown promise as a pretreatment to SODIS (Dawney \& Pearce 2012) and there is potential for the flocculating behavior of $\mathrm{NaCl}$ observed in pure clay solutions to apply to complex clay combinations (Mietta et al. 2009). The current research aims to further these studies by investigating the use of $\mathrm{NaCl}$ in reducing turbidity caused by a mixture of colloidal clay particles that reflects the natural composition of Vertisols. The effectiveness of this method as a means of treating 
turbid water may appreciably expand the geographic viability of the SODIS technology to regions where turbid water may have previously prevented the technology from being useful. This geographic/population expansion of the salt+SODIS method is investigated in detail in South Sudan using soil and population maps.

\section{Methodology}

The following water testing process was completed twice to observe the reproducibility of the results.

\section{Preparation of turbid samples}

Testing was performed to determine the behavior of $\mathrm{NaCl}$ in solutions containing $30 \%$ and $60 \%$ bentonite (sodium form) by mass with kaolinite, simulating the general composition of soils of the Vertisol type (Food and Agriculture Organization 2006). The preparation of the turbid water samples followed the process described by Gómez-Couso et al. (2009). Soil was added to $1000 \mathrm{ml}$ of distilled water to obtain turbidity levels of 50, 100, and 200 NTU to cover a range of possible field conditions (McGuigan et al. 1998).

\section{Concentrations of $\mathrm{NaCl}$}

Five different concentrations of $\mathrm{NaCl}$ were tested over a range of suitable values as outlined by Dawney and Pearce (2012). Testing was conducted using concentrations of 0.013 M, 0.017 M, 0.021 M, 0.026 M, 0.030 M, and 0.034 M, corresponding to $0.75 \mathrm{~g}$, $1.00 \mathrm{~g}, 1.25 \mathrm{~g}, 1.50 \mathrm{~g}, 1.75 \mathrm{~g}$, and $2.00 \mathrm{~g}$ of $\mathrm{NaCl}$ per liter of water.

\section{Coagulation-flocculation with $\mathrm{NaCl}$}

Standard jar test experiments were conducted to determine the flocculating behaviour of $\mathrm{NaCl}$ with each type of clay, as outlined in the ASTM Standard Practice for Coagulation-Flocculation Jar Test of Water (D2305-08). Temperature was held constant at $21 \pm 0.5^{\circ} \mathrm{C}$. Samples were flash-mixed for a period of 1 minute at $130 \mathrm{RPM}$ and then underwent slow-mix at 15 RPM for 20 minutes. Samples were then allowed to settle for 60 minutes, and qualitative and quantitative observations were recorded at 15-minute increments. Turbidity was measured with a portable Orbeco turbidimeter and is expressed in NTU, following the procedure outlined in the ASTM Standard Test Method for Determination of Turbidity Above 1 Turbidity Unit (D7315-07a). pH was monitored with a Fisher Accumet $1003 \mathrm{~N}$ portable $\mathrm{pH}$ meter. All experiments were run three times and the average turbidities for each sample were graphed.

\section{Quantity of sodium ions present in supernatant}

$25 \mathrm{ml}$ of supernatant was collected at a depth of $60 \mathrm{~mm}$ and then heated to $90^{\circ} \mathrm{C}$ for 300 minutes with $2 \mathrm{ml}$ of $1.0 \mathrm{M} \mathrm{HNO}_{3}$ to ensure any solids were completely dissolved in the solution. Quantitative inductively coupled plasma by optical emission spectroscopy (ICP-OES) analysis of the sodium ions present in the supernatant was then performed with a Varian Vista AX CCD Simultaneous ICP-AES. The entire procedure was repeated for a second suite of trials. 
South Sudan serves as a case country for investigating the applicability of the salt+SODIS method. South Sudanese soil types and population distributions were mapped in a geographic information system (GIS) using ArcMap 9.3. Geographically referenced data on soil types across Africa (FAO: Major Soils for Africa- FAO 1:5 Million Scale Soils Derived 2006) are comprised of 4,909 derived geographic units defined by dominant soil type (that which covers $40 \%$ or more of the land area). The geographic units are not political boundaries, but rather defined by the environmental characteristics of the soils. Using selection techniques, a layer that demonstrates where Vertisols are dominant was created.

This Vertisol layer was then overlaid with population data estimated from the 5th Sudan Population and Housing Census, 2008 (SSCCSE 2010) organized by county level geographic units. Data used here are based on the short form survey administered to everyone in the population. While censuses in Sudan have been limited by insecurity due to war and difficulty reaching remote villages, the 2008 census was conducted at a time of relative peace and employed GIS mapping and helicopters to reach remote villages, resulting in the most comprehensive population count made to date in South Sudan (SSCCSE 2010). County-level population data were entered into a geographic shapefile for county geographies produced by the United Nations (UN OCHA 2009).

Finally, the population (and child population under age 5) living in Vertisol areas was estimated using areal interpolation (Wu et al. 2005; Cai 2006). More specifically, an intersect was performed in the GIS system to combine geographic data on Vertisols with population data. The proportion of county territory (unit of analysis for population data) that falls within a Vertisol area was multiplied by the total population of the county to estimate the population living within each South Sudanese county in Vertisol areas. County level findings were then aggregated to the state level for reporting, the key assumption being that the population is evenly geographically dispersed within each county. This method produces only a rough estimate of the actual number of people affected. Data from the long form of the 5th Sudan Population and Housing Census (2008) estimate the proportion of the population in each state who lack access to clean drinking water. These proportions were then applied to our estimates of the population living in Vertisol areas to construct a rough estimate of the number of people without access to clean drinking water who live in Vertisol areas in South Sudan, and who may benefit from the salt+SODIS method.

\section{Results of bench tests}

$\mathrm{NaCl}$ was shown to be effective at reducing turbidity in dispersions containing just 30\% bentonite by mass. Figures 1 and 2 illustrate the settling of solutions containing $30 \%$ and $60 \%$ bentonite by mass (with kaolinite), respectively. All data points shown are the average of three measurements with the turbidimeter, corresponding to a maximum error of $5.5 \%$. This error is well within the confines of the context of reducing turbidity of water to the recommended SODIS threshold.

As shown in Figure 3, for some samples the resulting sodium concentration in the supernatant exceeded that which was added to the clay solution. This is due to a combination of latent sodium content in the clay and small errors in the preparation of the 
samples for ICP/OES analysis that become magnified in the process of converting values observed in the $25 \mathrm{~mL}$ sample to concentrations in one liter.

\section{Discussion}

NaCl Turbidity Reduction Effectiveness

The results show that $\mathrm{NaCl}$ can effectively facilitate settling in water containing mixtures of high-activity and low-activity clays, as shown by the results of settling of dispersions containing $30 \%$ and $60 \%$ bentonite by mass. For dispersions of $30 \%$ bentonite at an initial turbidity of $50 \mathrm{NTU}, 1250 \mathrm{mg}$ of $\mathrm{NaCl}$ was required. For the higher initial turbidities of 100 and 200 NTU, $1500 \mathrm{mg} / \mathrm{L}$ and $1750 \mathrm{mg} / \mathrm{L}$ of NaCl were required, respectively. More favorable is the result that only $1000 \mathrm{mg} / \mathrm{L}$ of $\mathrm{NaCl}$ was required to sufficiently settle all tested dispersions containing $60 \%$ bentonite by mass. Of those solutions that did not settle to below 30 NTU in 60 minutes, some may only require a longer settling period in order to breach the threshold. Of particular note are the dispersions composed of $30 \%$ bentonite by mass, as the general settling trend suggests that with slightly more time, all dispersions would have settled below 30 NTU using as little as $1250 \mathrm{mg} / \mathrm{L}$ of $\mathrm{NaCl}$.

The implications of these findings suggest that water sourced from geographic regions principally containing high-activity clays, such as Vertisols, may potentially be treated with $\mathrm{NaCl}$ to reduce turbidity caused by the clay particles. It should be pointed out here that many compounds in addition to clays can be responsible for turbidity such as organic materials and tannins and that field trials using low-cost open-source analytical equipment (Kelley et al. 2014; Wijnen et al. 2014) will be needed to verify the results of these lab tests before deployment is recommended for any specific application. Case study: South Sudan

The country of South Sudan provides a case example of the scope of impact that this method may have. Figure 4 shows the population distribution of South Sudan with respect to Vertisols, and illustrates significant potential for SODIS to be expanded in this region. About $40 \%$ of the land area in South Sudan (about 252,000 $\mathrm{km}^{2}$ ) is dominated by Vertisols, and about 3.2 million people, including over 500,000 children under age 5, live in those areas (see Table 1). Furthermore, an estimated 1.56 million South Sudanese people who live in Vertisol areas do not currently have access to an improved drinking water source and may directly benefit from the salt+SODIS method (see Table 2).

\section{Bentonite Jumpstart Effect}

The second implication of this study is that turbidity in source water may be addressed through the application of a small-scale jumpstart, a process by which bentonite is added to the target solution to speed up the flocculating process (Yang et al. 2007). This is a common step in industrial water and wastewater practices but the current study shows that it has potential for application in the context of HWT. As flocculation occurs most efficiently in water with a relatively high percentage of bentonite and at higher turbidity (Figures 1 and 2), it follows that where water is not sufficiently turbid to flocculate with $\mathrm{NaCl}$, this jumpstart effect may facilitate the process.

\section{Future studies}


It is recommended that the flocculating behaviour of $\mathrm{NaCl}$ with dispersed particles of calcium and magnesium bentonite/montmorillonite be investigated in bench tests, as these forms of bentonite are commonly found in the field, and have less swelling properties than the sodium form (Al-Rawas \& Goosen 2006). In addition, the jumpstart effect with bentonite and salt should be compared to the use of Moringa. Based on that investigation and the results of the current study, it may follow that this research should be expanded to the field in order to test the method against naturally occurring Vertisols. Should this method prove to be effective in the field, a detailed life-cycle analysis should be performed to examine its potential for appropriate and sustained use in target populations. In addition, future work should include full microbiological studies to explore the effectiveness of salt+SODIS at demonstrating an advantage in purifying drinking water that is caused by the reduced turbidity.

It is important to acknowledge that the current study does not compare the resulting sodium in the supernatant to allowable or tolerable health and taste limits. Additional work is needed to look at health effects such as hypernatremia and hyperchloremia risk associated with ingestion of high salt concentration water. This is particularly important for infants under 5 years old, which is the age group most at risk of diarrhoeal and waterborne disease and the most likely to benefit from the SODIS method in regions with contaminated water. There is a significant gap in data in this regard as it pertains to many populations in developing regions; as such, it is recommended that research be conducted to explore how the proposed $\mathrm{NaCl}$ treatment may affect the health of potential users both in the short and long term. Future work is needed to determine if this methodology would be socially and culturally acceptable in appropriate regions identified by the GIS techniques provided above. This can start with interviews of practitioners in the refugee camps to gauge their opinions and expand to interviewing individuals in rural communities on the viability of the technique in specific regions. This work would include expanding the GIS component of this study globally. Then, for example, work is needed to determine if the extra work-load associated with the salt step is tolerable in addition to the taste in all the identified regions. This $\mathrm{NaCl}$ technique should be considered with other additives, such as the recent findings that psoralens and lime acidity both interact synergistically with UV radiation to accelerate inactivation of microbes for the SODIS method (Harding and Schwab, 2012). $\mathrm{NaCl}$ and lime juice could work synergistically as well to solve potential taste and time challenges as the accelerated inactivation could potentially make up for the additional settling time and the combination could lead to more palatable water flavor.

Finally it should be noted that SODIS practitioners have some concerns about the reproducibility and reliability of the SODIS method beyond the use of high turbidity water that were not addressed in this study. Specifically, solar radiation variability in both total intensity and the spectral distribution of the solar flux (especially UV radiation) can alter the acceptable exposure time for the SODIS method to enable the safe drinking of treated water. As both the total flux and the spectrum varies with weather, temporally, geographically, and from the contributions from the micro-environments in which the SODIS are deployed it is not possible to know if an appropriate exposure was made without some form of a sensor. In order to expand the geographic reach of the SODIS method to the furthest extent possible to help the approximately one billion people that need it - a simple, easy-to-under stand, low-cost and robust method of sensing is needed 
to determine if a particular water sample has had enough UV exposure to be safe to drink. One potential solution is to use a small UV sensitive film sticker as a low-cost UV dose monitor to improve the reliability of the SODIS method. Such a method would take into account both the variations in solar flux but also the turbidity of a given batch of water as it could be adhered to the under surface of the bottle. This would add a small cost to each batch above the standard SODIS method, but could allay the concerns and make the method more reliable. Future work is needed to evaluate the technical, economic, and social acceptability of such a solution.

\section{Conclusions}

SODIS has shown to be an effective means of providing microbiologically clean water to at-risk populations in developing countries around the world, but its expansion to certain regions may be limited by a lack of available technology to first treat turbid source water. The current study suggests that this gap may be addressed through the use of $\mathrm{NaCl}$ in combination either with naturally occurring high-activity clays, or through the addition of bentonite to jumpstart flocculation and facilitate the settling of dispersed particles. Focusing only on the population of South Sudan, an impoverished and wartorn nation where only half of the population has access to an improved water source, an estimated 3.2 million people, including over 500,000 children under age 5, live in Vertisol areas. An estimated 1.5 million South Sudanese people who live in Vertisol areas do not currently have access to an improved drinking water source and may directly benefit from the salt+SODIS method. Immediate future work should address the effectiveness of $\mathrm{NaCl}$ at reducing turbidity in water containing various forms and concentrations of bentonite. Future studies should also examine the potential impacts of sustained use of this technology on user health, and if it can be applied to the removal of microbiological content in addition to turbidity.

\section{References}

Al-Rawas, A.A. \& Goosen, M.F.A., 2006. Expansive soils: recent advances in characterization and treatment. (Taylor \& Francis Group: London).

Akther, S., Hwang, J. \& Lee, H., 2008. Sedimentation characteristics of two commercial bentonites in aqueous suspensions. Clay Miner. 43, 449-457.

Batonio, A., Hartemink, A., Lungu, O., Naimi, M., Okoth, P., Smaling, E., Thiombiano, L., 2006. Background Paper Prepared for the African Fertilizer Summit. African Soils: Their Productivity and Profitability of Fertilizer Use.

Berney, M., Weilenmann, H., Simonetti, A. \& Egli, T., 2006. Efficacy of solar disinfection of Escherichia coli, Shigella flexneri, Salmonella Typhimurium and Vibrio cholerae. Journal of Applied Microbiology 101, 828-836.

Buitenhuis, A. J., Zelenika I., and Pearce, J. M., 2010. Open Design-Based Strategies to Enhance Appropriate Technology Development. Proceedings of the 14th Annual National Collegiate Inventors and Innovators Alliance Conference : Open, pp. 1-12. 
Cai Q., Rushton, G., Bhaduri, B., Bright, E., and Coleman, P., 2006. Estimating small-area populations by age and sex using spatial interpolation and statistical inference methods. Transactions in GIS 10 (4): 577-98.

Cairncross, S., Hunt, C., Boisson, S., Bostoen, K., Curtis, V., Fung, I.C., Schmidt, W.P., 2010. Water, sanitation and hygiene for the prevention of diarrhoea. International Journal of Epidemiology 39, i193-i205.

Clasen, T., Schmidt, W.P., Rabie, T., Roberts, I. \& Cairncross, S., 2007. Interventions to improve water quality for preventing diarrhoea: systematic review and meta-analysis. BMJ 334, 782-782.

Clasen, T., Cairncross, S., Haller, L., Bartram, J. \& Walker, D., 2007. Cost-effectiveness of water quality interventions for preventing diarrhoeal disease in developing countries. Journal of Water and Health 5, 599.

Conroy, R.M., Elmore-Meegan, M., Joyce, T., McGuigan, K.G. \& Barnes, J., 1996. Solar disinfection of drinking water and diarrhoea in Maasai children: a controlled field trial. Lancet 348, $1695-1697$.

Conroy, R.M., Meegan, M.E., Joyce, T., McGuigan, K. \& Barnes, J. Solar disinfection of drinking water protects against cholera in children under 6 years of age. Archives of Disease in Childhood 85, 293-295 (2001).

Conroy, R.M., Meegan, M.E., Joyce, T., McGuigan, K. \& Barnes, J. Solar disinfection of water reduces diarrhoeal disease: an update. Archives of Disease in Childhood 81, 337-338 (1999).

Dawney, B. \& Pearce, J.M., 2012. Optimizing the Solar Water Disinfection (SODIS) Method by Decreasing Turbidity with NaCl. Journal of Water, Sanitation, and Hygiene for Development 2(2, 87-94.

Dejung, S., Wegelin, M., Fuentes, I., Almanza, G., Jarro, R., Navarro, L., Arias, G., Urquieta, E., Torrico, A., Fenandez, W., Iriarte, M., Birrer, C., \& Stahel, W., 2007. Effect of solar water disinfection (SODIS) on model microorganisms under improved and field SODIS conditions. Journal of Water Supply: Research and Technology—AQUA 56, 245.

Elliott, P. \& Brown, I. Sodium Intakes Around the World. Background document prepared for the Forum and Technical meeting on Reducing Salt Intake in Populations (Paris 5-7th October 2006).

Eswaran, H. \& Cook, T., 1988. Classification and management-related properties of Vertisols. Proceedings of a Conference Held at ILCA, Addis Ababa, Ethiopia 31 August-4 September 1987.

Ferreira, R.S., Napoleao, T.H., Santos, A.F.S., Sa, R.A., Carneiro-da-Cunha, M.G., Morais, M.M.C., Silva-Lucca, R.A., Oliva, M.L.V., Coelho, L.C.B.B., Paiva, P.M.G., 2011. Coagulant and antibacterial activities of the water-soluble seed lectin from Moringa oleifera. Letters in Applied Microbiology 53, 186-192.

Fewtrell, L., Kaufman, R., Kay, D., Enanoria, W., Haller, L., \& Colfordjr, J., 2005. Water, sanitation, and hygiene interventions to reduce diarrhoea in less developed countries: a systematic review and meta-analysis. The Lancet Infectious Diseases 5, 42-52. 
Food and Agriculture Organization of the United Nations, 2006. World reference base forsoil resources 2006. (Food and Agriculture Organization: Rome).

Gibbs, R.J., 1983. Coagulation rates of clay minerals and natural sediments. SEPM Journal of Sedimentary Research 53.

Gibbs, R.J. 1985. Settling velocity, diameter, and density for flocs of illite, kaolinite, and montmorillonite. SEPM Journal of Sedimentary Research 55.

Gómez-Couso, H., Fontan-Sainz, M., McGuigan, K.G. \& Ares-Mazas, E., 2009. Effect of radiation intensity, water turbidity and exposure time on the survival of Cryptosporidium during simulated solar disinfection of drinking water. Acta Tropica 112, 43-48.

Gómez-Couso, H., Fontán-Saínz, M., Sichel, C., Fernández-Ibáñez, P. \& Ares-Mazás, E., 2009. Efficacy of the solar water disinfection method in turbid waters experimentally contaminated with Cryptosporidium parvum oocysts under real field conditions. Tropical Medicine and International Health 14, 620-627.

Graf, J., Zebaze Togouet, S., Kemka, N., Niyitegeka, D., Meierhofer, R., \& Gangoue Pieboji, J., 2010. Health gains from solar water disinfection (SODIS): evaluation of a water quality intervention in Yaoundé, Cameroon. Journal of Water and Health 8, 779-796.

Hadden, R.L., 2007. The Geology of Somalia: a Select Bibliography of Geology, Geography, and Earth Science. (US Army Corps of Engineers: Virginia) at <http://www.dtic.mil/cgibin/GetTRDoc?AD=ADA464006>

Harding, A.S., Schwab, K.J., 2012. Using Limes and Synthetic Psoralens to Enhance Solar Disinfection of Water (SODIS): A Laboratory Evaluation with Norovirus, Escherichia coli, and MS2. Am J Trop Med Hyg 86, 566-572.

Hsi, H. \& Clifton, D.F. 1960. Flocculation of selected clays by various electrolytes. Clays and Clay Minerals 9, 269-275.

Joyce, T., McGuigan, K., Elmo, M. \& Conroy, R., 1996. Inactivation of fecal bacteria in drinking water by solar heating. Applied and Environmental Microbiology 62, 399-402.

Kelley, C. D., Krolick, A., Brunner, L., Burklund, A., Kahn, D., Ball, W. P., \& Weber-Shirk, M. 2014. An Affordable Open-Source Turbidimeter. Sensors 14(4), 7142-7155.

McGuigan, K., Joyce, T., Conroy, R., Gillespie, J. \& Elmore-Meegan, M., 1998. Solar disinfection of drinking water contained in transparent plastic bottles : characterizing the bacterial inactivation process. Journal of Applied Microbiology 84, 1138-1148.

Meierhofer, R. \& Landolt, G., 2009. Factors supporting the sustained use of solar water disinfection - Experiences from a global promotion and dissemination programme. Desalination 248, 144-151.

Meierhofer, R. \& Wegelin, M., 2002. Solar water disinfection: A guide for the application of SODIS. at <http://www.sodis.ch/methode/anwendung/ausbildungsmaterial/index_EN> 
Mietta, F., Chassagne, C., Manning, A.J. \& Winterwerp, J.C., 2009. Influence of shear rate, organic matter content, $\mathrm{pH}$ and salinity on mud flocculation. Ocean Dynamics 59, 751-763.

Mintz, E., Bartram, J., Lochery, P. \& Wegelin, M., 2001. Not just a drop in the bucket: expanding access to point-of-use water treatment systems. American Journal of Public Health 91, 15651570.

Murthy, R.S., 1981. Distribution and properties of Vertisols and associated soils. In: Improving the management of India's deep black soils. Proceedings of the Seminar on Management of Deep Black Soils for Increased Production of Cereals, Pulses, and Oilseeds, New Delhi, India, 21 May 1981. ICRISAT (International Crops Research Institute for the Semi-Arid Tropics), Patancheru, Andhra Pradesh, India. pp. 9-16.

New York Times. South Sudan. Sept. 27, 2012.

$<$ http://topics.nytimes.com/top/news/international/countriesandterritories/southsudan/index.html>. Accessed 10/24/2012.

Panayiotopoulos, K.P., Barbayiannis, N. \& Papatolios, K., 2004. Influence of Electrolyte Concentration, Sodium Adsorption Ratio, and Mechanical Disturbance on Dispersed Clay Particle Size and Critical Flocculation Concentration in Alfisols. Communications in Soil Science and Plant Analysis 35, 1415-1434.

Pearce, J.M., 2012. The Case for Open Source Appropriate Technology. Environment, Development and Sustainability 14, 425-431.

Rijal, G.K. \& Fujioka, R.S., 2001. Synergistic effect of solar radiation and solar heating to disinfect drinking water sources. Water Science and Technology 43, 155-162.

Rose, A., Roy, S., Abraham, V., Holmgren, G., George, K., Balraj, V., Abraham, S., Muliyil, J., Joseph, A., \& Kang, G., 2006. Solar disinfection of water for diarrhoeal prevention in southern India. Archives of Disease in Childhood 91, 139-141.

Swindale, L.D., 1988. Developing, testing and transferring improved Vertisol technology: The Indian experience. Proceedings of a Conference Held at ILCA, Addis Ababa, Ethiopia 31 August4 September 1987.

Sobsey, M., 2002. Managing Water in the Home: Accelerated Health Gains from Improved Water Supply. (Department of Protection of the Human Environment, World Health Organization. WHO/SDE/WSH/02.07: 2002).

Southern Sudan Centre for Census, Statistics, and Evaluation [SSCCSE]. 2010. Southern Sudan Counts: Tables from the 5th Sudan Population and Housing Census, 2008.

Thapar, N., 2004. Diarrhoea in children: an interface between developing and developed countries. The Lancet 363, 641-653.

United Nations, OCHA. 2009. Sudan Administrative Boundaries Shapefile. United Nations Sudan Information Gateway. 
Wijnen, B., Anzalone, G.C., Pearce, J.M. 2014. Open-source Mobile Water Quality Testing Platform, Journal of Water, Sanitation and Hygiene for Development (in press).

World Water Assessment Programme (United Nations); UN-Water; UNESCO, 2009. Water in a Changing World. (UNESCO Publications; Earthscan: Paris; London).

Wu, S., Qiu, X., and Wang, L., 2005. Population estimation methods in GIS and remote sensing: A review. GIScience and Remote Sensing 42 (1): 58-74.

Yang, Y., Zhou, T., Qiao, Q. \& Chen, S., 2007. Experimental Study of Wastewater Treatment of Reactive Dye by Phys-Chemistry Method. Journal of China University of Mining and Technology 17, 96-100. 
Figures
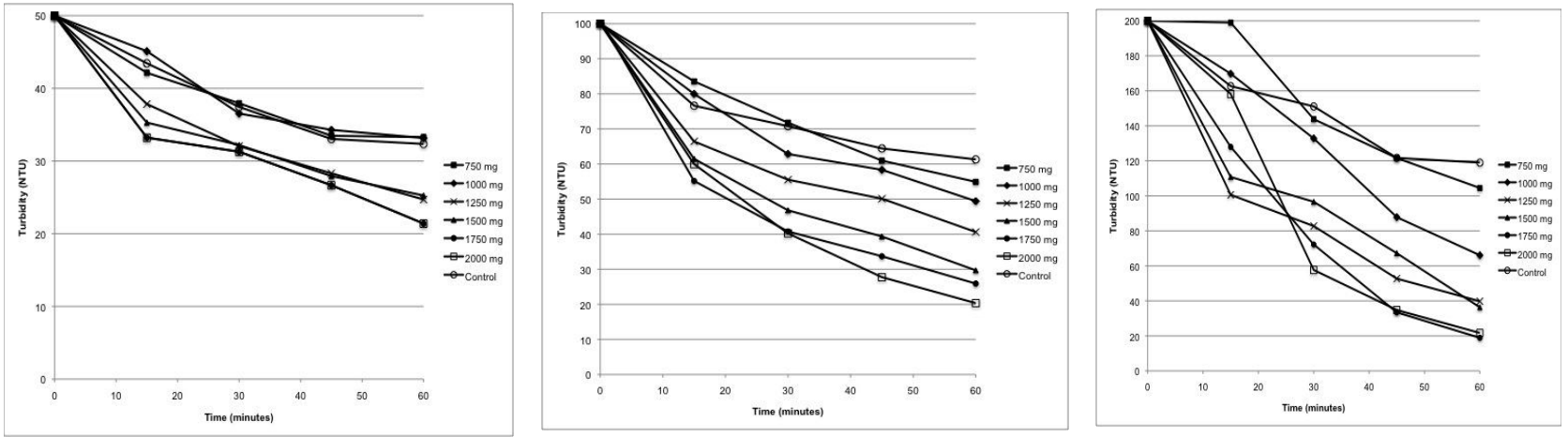

Figure 1. Settling of dispersions containing 30\% bentonite by mass from an initial turbidity of: a) 50 NTU, b) 100 NTU, and c) 200 NTU.
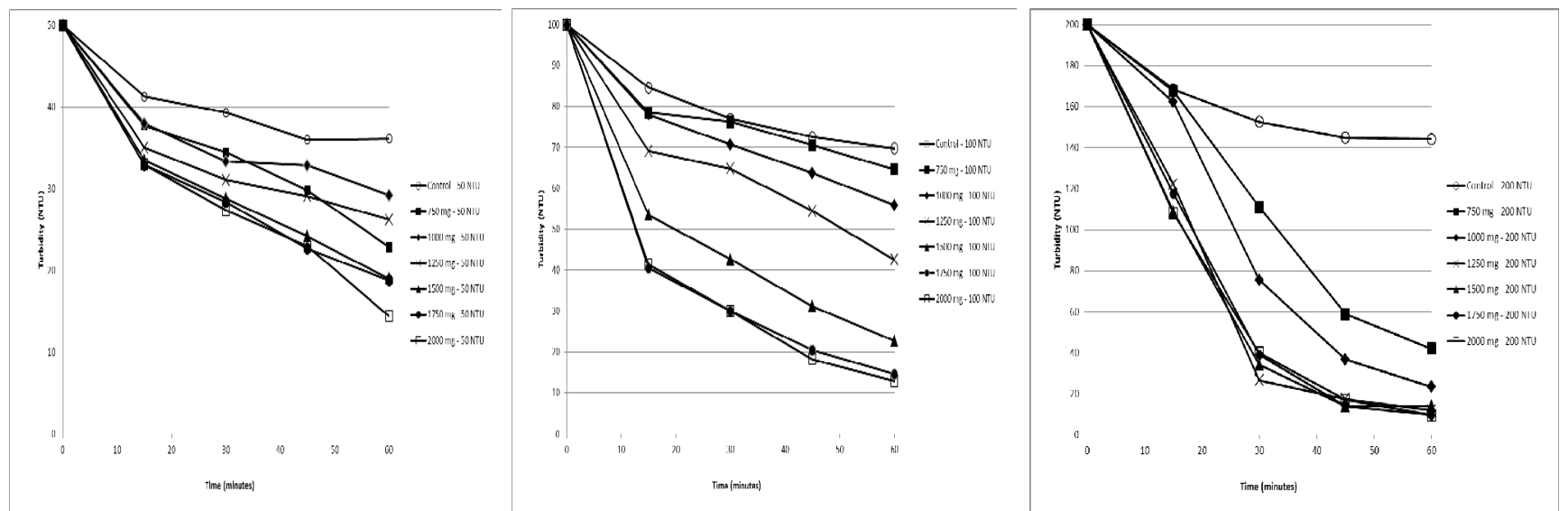

Figure 2. Settling of dispersions containing $60 \%$ bentonite by mass from an initial turbidity of: a) 50 NTU, b) 100 NTU, and c) 200 NTU. 


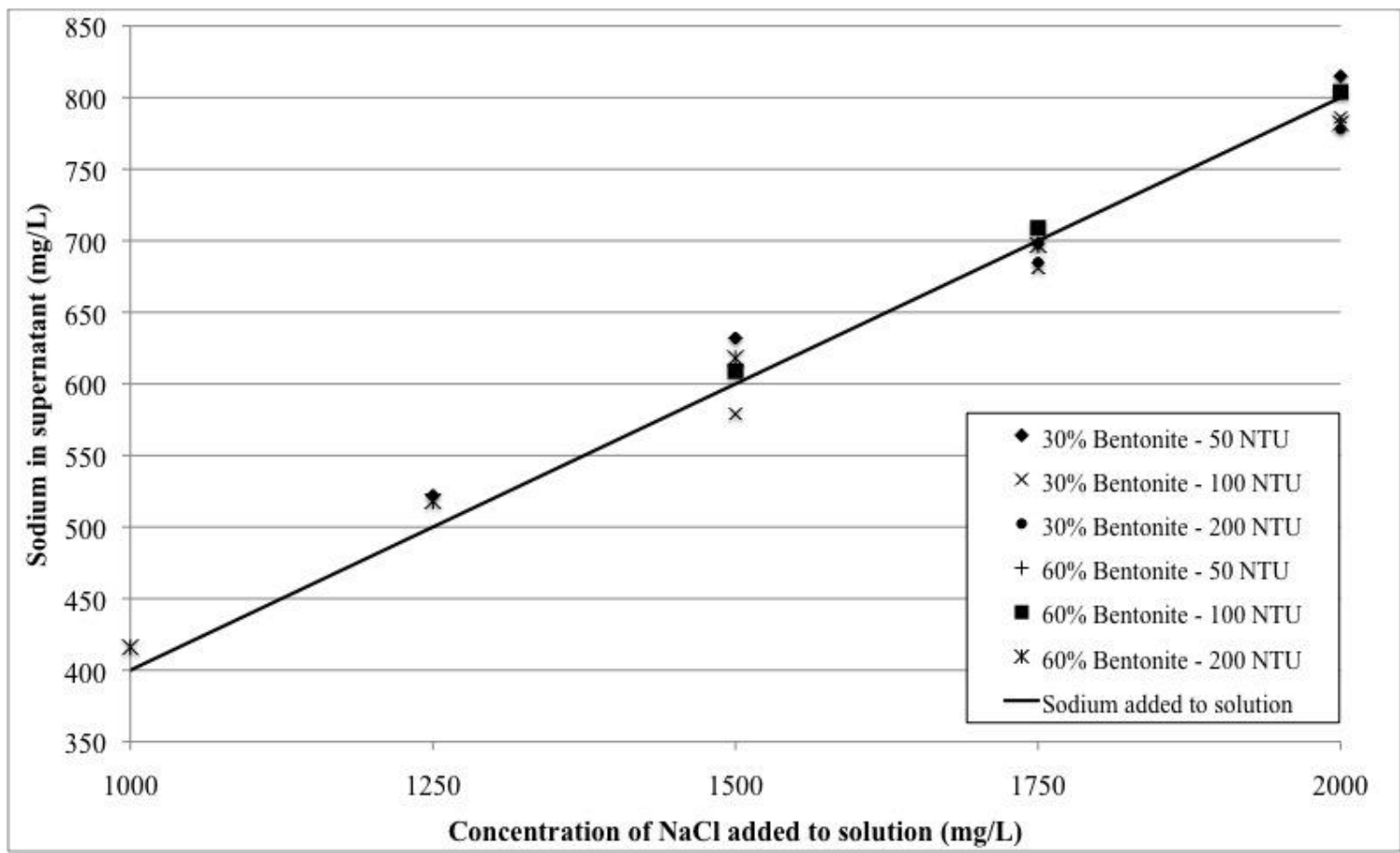

Figure 3. Sodium content remaining in supernatant after 60 minutes of settling with a final turbidity of less than 30 NTU. Ideal results tend toward the lower left-hand quadrant. 


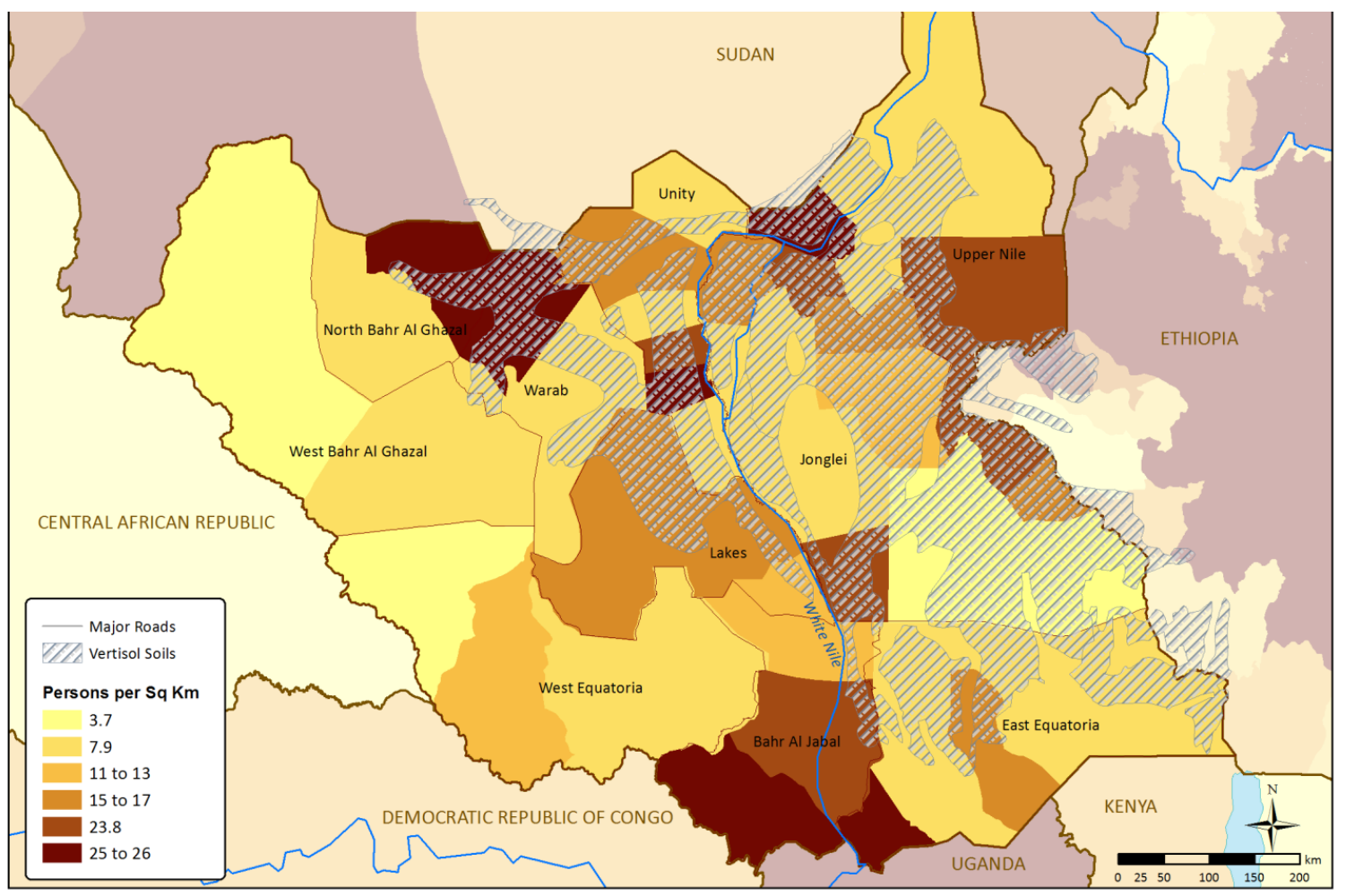

Figure 4. South Sudan population in Vertisol soil areas. Sources: 5th Sudan Population and Housing Census, 2008 and FAO Major Soils for Africa, 2006. 
Preprint: Brittney Dawney, Cheng Cheng, Richelle Winkler, Joshua M. Pearce. Evaluating the geographic viability of the solar water disinfection (SODIS) method by decreasing turbidity with NaCl: A case study of South Sudan. Applied Clay Science 99:194-200 (2014). DOI: 10.1016/j.clay.2014.06.032

Table 1: Estimated South Sudanese Population in Vertisol Soil Areas

\begin{tabular}{|c|c|c|c|c|c|c|}
\hline & \multicolumn{2}{|c|}{ Land Area } & \multicolumn{2}{|c|}{ Total Population } & \multicolumn{2}{|c|}{ Population under 5} \\
\hline & Sq Km & \% Vertisol & Number & \% Vertisol & Number & \% Vertisol \\
\hline Total Area & 633,112 & $39.8 \%$ & $8,260,490$ & $39.1 \%$ & $1,304,131$ & $39.5 \%$ \\
\hline Vertisol Soils & 251,861 & & $3,231,079$ & & 515,357 & \\
\hline
\end{tabular}

Source: Estimates are authors' calculations based on data from $5^{\text {th }}$ Sudan Population and Housing Census, 2008 and FAO Major Soils for Africa, 2006. 
Table 2: Estimated South Sudanese Population who may Benefit from Salt+SODIS by State

\begin{tabular}{lrr}
\hline \multicolumn{1}{c}{ State } & $\begin{array}{c}\text { Population in } \\
\text { Vertisol Areas }\end{array}$ & $\begin{array}{r}\text { Population without } \\
\text { Clean Water in Vertisol } \\
\text { Areas }\end{array}$ \\
\hline Upper Nile & & \\
Jonglei & 413,281 & 283,924 \\
Unity & $1,085,897$ & 412,641 \\
Warab & 322,603 & 182,916 \\
N. Bahr El Ghazal & 686,773 & 399,015 \\
W. Bahr El Ghazal & 140,632 & 65,816 \\
Lakes & 11,475 & 5,772 \\
W. Equatoria & 243,391 & 52,816 \\
C.Equatoria /Bahr Al Jabal & 0 & 0 \\
E. Equatoria & 42,485 & 24,939 \\
\hline South Sudan Total & 284,541 & 135,157 \\
\hline
\end{tabular}

Source: Estimates based on data from $5^{\text {th }}$ Sudan Population and Housing Census, 2008 and FAO Major Soils for Africa, 2006. 